\title{
РОЗРОБКА СИСТЕМИ ОЦІНЮВАННЯ ЯКОСТІ ТОРГОВЕЛЬНОГО ОБСЛУГОВУВАННЯ ПОКУПЦІВ
}

Метою роботи є дослідження застосування розробленої нечіткої моделі щзодо оцінювання якості торгівельного обслуговування покупців на нечіткій логіці у поєднанні з сучасними інформаційними технологіями задля забезпечення підвищення ефективності організації процесу реалізації товарів.

У статті представлена розроблена система оцінювання якості торгівельного обслуговування покупиів, яка дозволяє здійснювати визначення рівня якості торгівельного обслуговування покупиів на основі наступних сервісів: побудови нечіткої експертно-лінгвістичної бази правил стосовно визначення рівня якості торгівельного обслуговування покупців; перетворення нечіткого значення вхідних змінних в чітке число у відповідності до діапазону виміру кожного контрольованого параметру нечіткої моделі; налаштування значень вхіднх параметрів, щзо забезпечує можливість аналізу впливу зміни значень вхідних параметрів на значення результуючої змінної.

Досліджено застосування розробленої нечіткої моделі щуодо оцінювання якості торгівельного обслуговування покупиів на нечіткій логічі у поєднанні з сучасними інформачійними технологіями задля забезпечення підвищення ефективності організації процесу реалізації товарів.

Представлено опис функиіоналу системи оичнювання якості торгівельного обслуговування покупців у вигляді діаграми варіантів використання об 'єктно-орієнтованої моделі системи оцінювання якості торгівельного обслуговування покупців та загальний алгоритм функціонування системи за допомогою UML-діаграми - діаграми станів.

Ключові слова: система, моделювання, торгівельне підприємство, нечітка логіка, проектування, діаграма, UML-моделювання.

О. Л. ОЛЬХОВСКАЯ

Донбасская государственная машиностроительная академия, г. Краматорск ORCID: 0000-0001-9494-2338

Е. Ю. ГУДКОВА

Донбасская государственная машиностроительная академия, г. Краматорск ORCID: 0000-0003-0290-7880

И. А. САБАЙДАШ

Донбасская государственная машиностроительная академия, г. Краматорск

\section{РАЗРАБОТКА СИСТЕМЫ ОЦЕНИВАНИЯ КАЧЕСТВА ТОРГОВОГО ОБСЛУЖИВАНИЯ ПОКУПАТЕЛЕЙ}

Целью работы является исследование применения разработанной нечеткой модели для оченки качества торгового обслуживания покупателей на нечеткой логике в сочетании с современными информационными технологиями для обеспечения повышения эффективности организации процесса реализачии товаров.

В статье представлена разработанная система оценки качества торгового обслуживания покупателей, позволяющая осуществлять определение уровня качества торгового обслуживания покупателей на основе следующих сервисов: построения нечеткой экспертно-лингвистической базы правил определения уровня качества торгового обслужсивани покупателей; преобразование нечеткого значения входных переменных в четкое число, в соответствии с диапазоном измерения каждого контролируемого параметра нечеткой модели; настройки значений входных параметров, что обеспечивает возможность анализа влияния изменения их значений на значение результирующей переменной.

Исследовано применение разработанной нечеткой модели для оченки качества торгового обслуживания покупателей на нечеткой логике в сочетании с современными информационными технологияли для обеспечения повымения эффективности организациии процесса реализации товаров. 
Представлено описание функиионала системь оценки качества торгового обслуживания покупателей в виде диаграммы вариантов использования объектно-ориентированной модели системь оценки качества торгового обслужсивания покупателей и общий алгоритм функционирования системы с помощьью UML-диаграммы - диаграммы состояний.

Ключевые слова: система, моделирование, торговое предприятие, нечеткая логика, проектирование, диаграмма, UML-моделирование.

O. OLKHOVSKA

Donbas's State Engineering Academy, Kramatorsk ORCID: 0000-0001-9494-2338

K. HUDKOVA

Donbas's State Engineering Academy, Kramatorsk ORCID: 0000-0003-0290-7880

I. SABAIDASH

Donbas's State Engineering Academy, Kramatorsk

\section{DEVELOPMENT OF EVALUATION SYSTEM QUALITY OF TRADE SERVICE OF BUYERS}

The aim of the work is to study the application of the developed fuzzy model to assess the quality of customer service on fuzzy logic in combination with modern information technology to improve the efficiency of the organization of the sales process.

The article presents a developed system for assessing the quality of customer service, which allows to determine the level of quality of customer service on the basis of the following services: building a fuzzy expertlinguistic base of rules for determining the quality of customer service; converting the fuzzy value of the input variables into a clear number according to the measurement range of each controlled parameter of the fuzzy model; setting the values of input parameters, which provides the ability to analyze the impact of changes in the values of input parameters on the values of the resulting variable.

The application of the developed fuzzy model for assessing the quality of customer service on fuzzy logic in combination with modern information technology to improve the efficiency of the organization of the sales process.

The description of the functionality of the customer service quality assessment system is presented in the form of a diagram of options for using the object-oriented model of the customer service quality assessment system and the general algorithm of the system using UML-diagram - state diagram.

Keywords: system, modeling, trading company, fuzzy logic, design, diagram, UML-modeling.

\section{Постановка проблеми}

Інформаційні технології за останні роки проникли у всі аспекти діяльності сучасного підприємства - менеджмент, маркетинг, закупівлю, збут, фінанси, управління персоналом, виробництво. Інформаційні системи $є$ найбільш зручним і ефективним рішенням та інструментом аналітичної роботи 3 даними, відкривають широкі можливості проведення різних видів аналізу та подання результатів у потрібних форматах.

Впроваджуючи сучасні інформаційні системи господарюючі суб'єкти отримують передові технології управління, які допомагають підвищити конкурентоспроможність підприємства в цілому.

Підвищення ролі соціально-економічного фактору часу в сучасному житті набуло жорсткої вимоги, щодо скорочення затрат часу на придбання товарів, змінило уявлення про якість торгівлі i торгівельних послуг. Саме тому сьогодні особлива увага повинна надаватися впровадженню прогресивних систем торгівельного обслуговування. Основна вимога, яка ставиться до цих систем з боку покупців відчутне зниження затрат часу на придбання товарів за умов розширення асортименту товарів, збільшення обсягів послуг і підвищення їх якості. Однак система масового товаропостачання населення через торгівельні підприємства орієнтована на потік покупців, самообслуговування, групову, масову рекламу й інформацію покупців.

Особливість підприємств роздрібної торгівлі полягає у безпосередньому контакті торгівельнооперативного персоналу із кінцевими споживачами. Це висуває підвищені вимоги до якості обслуговування і кваліфікації персоналу підприємств роздрібної торгівлі [1].

\section{Аналіз останніх досліджень і публікацій}

Обслуговування справді високого рівня, що цілком відповідає найвищим потребам і запитам споживачів, може бути забезпечене лише тими учасниками товарного ринку, які прагнуть до досягнення вимог найвищих стандартів [2].

Відповідно, чим більш досконала система торгівельного обслуговування, тим вищий рівень його якості у конкретному підприємстві торгівлі і тим значнішою буде його конкурентна перевага. Саме 
необхідність цілеспрямовано впливати на підвищення конкурентоспроможності об'єкта торгівлі [3] визначає актуальність дослідження 3 питань оцінювання якості обслуговування, зокрема за допомогою сучасного економіко-математичного інструментарію.

Створення ефективної системи щодо оцінювання якості торгівельного обслуговування покупців дозволить вирішити низку завдань із забезпечення підвищення ефективності рівня управління якістю торгівельного обслуговування та процесом реалізації товарів в цілому.

3 урахуванням специфіки організації та ведення вітчизняного торгівельного бізнесу нагальним $\epsilon$ застосування сучасного математичного інструментарію, який в повному обсязі дозволить врахувати українські реалії ведення торгівельного бізнесу та здійснювати оцінювання рівня якості торговельного обслуговування покупців. Відповідно, для побудови нечіткої моделі щодо оцінювання якості торговельного обслуговування покупців застосуємо методологічний підхід на основі теорії нечіткої логіки [4-5].

\section{Формулювання мети дослідження}

Метою роботи є дослідження застосування розробленої нечіткої моделі щодо оцінювання якості торгівельного обслуговування покупців на нечіткій логіці у поєднанні з сучасними інформаційними технологіями задля забезпечення підвищення ефективності організації процесу реалізації товарів.

\section{Викладення основного матеріалу дослідження}

Етапи методологічного підходу до побудови нечіткої економіко-математичної моделі оцінювання якості торгівельного обслуговування покупців торгівельного підприємства [4-5]:

Етап 1. Вибір показників.

На даному етапі формується набір показників, які дозволяють зробити обгрунтований аналіз якості торговельного обслуговування покупців торгівельного підприємства, визначити оптимальність рівня якості торговельного обслуговування покупців.

Серед показників, що характеризують діяльність підприємств роздрібної торгівлі, важливе місце займає рівень обслуговування покупців [3; 6]. Від нього значної мірою залежить успіх підприємства у конкурентній боротьбі на споживчому ринку, його імідж і навіть ринкова вартість. Рівень обслуговування покупців виявляється у процесі реалізації товарів і характеризує цей процес. Результатом цього процесу $є$ задоволення потреб покупців у товарах. Тому всі внутрішні фактори економічного, організаційно-технічного і технологічного характеру, що впливають на товарооборот підприємства торгівлі, визначають також і стан торгівельного обслуговування, відображаючи умови торгівельної діяльності і залежність від роботи відповідних служб апарату управління торгівельного підприємства і керівництва. Вони налагоджують механізм комерційних відносин, процес постачання товарів, впровадження прогресивних технологій обслуговування покупців та забезпечують розв'язання інших проблем, що виникають у процесі функціонування торгівельних об'єктів. Все це майже не залежить від торгівельно-оперативних працівників, а лише створює передумови для успішної їх роботи. Від персоналу торгівельного підприємства повністю залежить лише якість самого процесу обслуговування покупців на момент продажу товарів. Тут важливу роль відіграють професійна майстерність продавця, його особиста культура, витримка, такт, зацікавленість у результатах праці.

Таким чином, високий рівень торгівельного обслуговування забезпечується ефективним поєднанням належної організації обслуговування з якістю процесу обслуговування.

Поняття «рівень обслуговування покупців» визначається рядом конкретних елементів, які відіграють різну роль у забезпеченні цього рівня. До найбільш важливих елементів відносяться [6]:

- наявність у магазині широкого і стійкого асортименту товарів, що забезпечує задоволення попиту;

- застосування прогресивних методів продажу товарів, що забезпечують найбільш зручні й мінімальні витрати часу на здійснення покупок;

- надання покупцям додаткових торговельних послуг, пов'язаних зі специфікою реалізованих товарів;

- широке використання засобів внутрішньої реклами й інформації;

- висока професійна кваліфікація персоналу, який безпосередньо здійснює процес обслуговування покупців;

- повне дотримання встановлених правил продажу товарів і правил торговельного обслуговування

Для кількісної оцінки якості торгівельного обслуговування покупців існує система показників, які відображають стан товарної пропозиції, організації процесу продажу товарів і обслуговування покупців [6]:

- коефіцієнт завершеності покупок;

- коефіцієнт, що характеризує рівень надання послуг покупцям;

- коефіцієнт, що характеризує затрати часу покупців на купівлю товарів;

- коефіцієнт, що характеризує якість обслуговування на думку покупців; 
- коефіцієнт оновлення товарного асортименту;

- коефіцієнт гармонійності товарного асортименту;

- коефіцієнти широти, глибини, стійкості асортименту.

Під час аналізу рівня торговельного обслуговування кожен із основних елементів, що визначають цей рівень, повинен отримати кількісну оцінку і бути врахованим при визначенні узагальнюючого показника.

Враховуючи особливості процесу обслуговування клієнтів та зазначене вище для побудови моделі оцінювання якості торгівельного обслуговування покупців будемо використовувати набір факторів $x_{i}, i=\overline{1,6}$, за якими можна робити висновок щодо рівня якості торгівельного обслуговування покупців:

$$
Y=f\left(x_{1}, \ldots, x_{6}\right)
$$

На основі проведеного грунтовного аналізу наукових літературних джерел та знань експертів даної предметної області (в томи числі менеджмент підприємства) для оцінювання якості торгівельного обслуговування покупців сформовано наступну множину пояснюючих змінних:

- показник стійкості асортименту товарів $\left(x_{1}\right)$;

- показник впровадження прогресивних методів продажу товарів $\left(x_{2}\right)$;

- показник додаткового обслуговування покупців $\left(x_{3}\right)$;

- показник затрат часу покупців на очікування обслуговування $\left(x_{4}\right)$;

- показник завершеності покупки товарів $\left(x_{5}\right)$;

- показник якості праці колективу $\left(x_{6}\right)$.

Етап 2. Опис лінгвістичних змінних.

Поняття лінгвістичної змінної відіграє важливу роль в нечіткому логічному висловлюванні та в ухваленні рішень на основі наближених міркувань.

На даному етапі відбувається лінгвістичний опис як вхідних $x_{i}, i=\overline{1,6}$, так і результуючої $Y$ змінних, тобто значення подаються не числами, а словами природної мови - термами. Терм $є$ елементом терм-множини. Терм-множина складає множину всіх можливих значень лінгвістичної змінної.

Таким чином, на даному етапі визначаються терм-множини, що в подальшому будуть застосовуватися для оцінювання рівня якості торгівельного обслуговування покупців $Y$, вхідних змінних $x_{i}, i=\overline{1,6}$, та можливого діапазону змінювання кожного терму.

Дослідження основних аспектів процесу реалізації товарів, зокрема процесу обслуговування покупців, дозволило сформувати множину можливих лінгвістичних значень показників $x_{i}, i=\overline{1,6}$, для використання в розрахунках на основі нечіткої моделі. Так, оцінка вхідних показників відбувається із застосуванням чотирьох якісних термів $\{B, C, H C, B\}$, що визначають рівень показника, а саме: «B»високий рівень показника, « $C »-$ середній рівень показника, «HC»- рівень показника нижче середнього, «H» - низький рівень показника. Множину значень вихідної лінгвістичної змінної $Y$, що визначає рівень якості торгівельного обслуговування покупців складають терми: «B»- високий рівень, « $C »-$ середній рівень та «H»- низький рівень $-\{B, C, H\}$.

Виходом моделі є визначення рівня якості торгівельного обслуговування покупців. Відповідно, розроблена нечітка економіко-математична модель після проведення розрахунків знаходить значення вихідної змінної із множини заданих лінгвістичних термів $\{B, C, H\}$.

Результуюча змінна $Y$ буде вимірюватися у діапазоні $[0 ; 1]$, де інтервал $[0 ; 0,3)$ складає інтервал значень, що визначають рівень якості торгівельного обслуговування покупців як низький («Н»). Інтервал $(0,3 ; 0,6]$ складає інтервал значень, що визначають рівень якості торгівельного обслуговування покупців як середній (« $C »)$. Терм «B» присвоюється, якщо виконується умова: $Y>0,6$.

Діапазон виміру вхідних змінних - $[0 ; 1]$, де:

- інтервал $[0 ; 25]$ складає інтервал значень, що визначають рівень вхідного показника - низький;

-інтервал [26; 50] складає інтервал значень, що визначають рівень вхідного показника - нижче середнього;

-інтервал [51; 75] складає інтервал значень, що визначають рівень вхідного показника - середній;

-інтервал [76; 100] складає інтервал значень, що визначають рівень вхідного показника - високий.

Етап 3. Формування набору правил.

На даному етапі формується нечітка база знань, яка є сукупністю експертно-лінгвістичних правил. Грунтуючись на цій базі знань модель дозволяє отримати нечіткий логічний висновок стосовно рівня якості торгівельного обслуговування покупців на основі відповідної вхідної інформації.

Нечітка база знань щодо визначення рівня якості торгівельного обслуговування покупців представлена в таблиці 1. Для їі побудови використано експертні лінгвістичні правила типу «ЯКЩО ТОДІ», при цьому впевненість експерта в кожному правилі дорівнює одиниці. 

одного.

Формування набору правил виконано за умови: правила не перетинаються та не дублюють одне

База нечітких правил щодо визначення рівня якості торгівельного обслуговування покупців

\begin{tabular}{|c|c|c|c|c|c|c|c|}
\hline \multirow{2}{*}{\multicolumn{6}{|c|}{ Вхідні змінні }} & \multirow{3}{*}{$\begin{array}{c}\text { Результуюча змінна } \\
Y \\
\end{array}$} & \multirow{3}{*}{$\begin{array}{c}\text { Вага } \\
\text { правила }\end{array}$} \\
\hline & & & & & & & \\
\hline$x_{1}$ & $x_{2}$ & $x_{3}$ & $x_{4}$ & $x_{5}$ & $x_{6}$ & & \\
\hline $\mathrm{B}$ & $\mathrm{B}$ & $\mathrm{B}$ & $\mathrm{B}$ & $\mathrm{B}$ & $\mathrm{B}$ & \multirow[t]{2}{*}{ 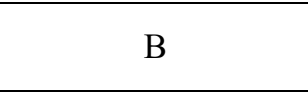 } & $\omega_{1}^{\mathrm{B}}$ \\
\hline $\mathrm{C}$ & $\mathrm{C}$ & B & $\mathrm{C}$ & $\mathrm{B}$ & B & & $\omega_{2}^{\mathrm{B}}$ \\
\hline $\mathrm{C}$ & $\mathrm{C}$ & $\mathrm{C}$ & $\mathrm{C}$ & $\mathrm{C}$ & $\mathrm{C}$ & \multirow{2}{*}{$\mathrm{C}$} & $\omega_{1}^{C}$ \\
\hline $\mathrm{C}$ & $\mathrm{B}$ & $\mathrm{C}$ & $-\mathrm{B}$ & $\mathrm{C}$ & $\mathrm{C}$ & & $\omega_{2}^{C}$ \\
\hline $\mathrm{C}$ & $\mathrm{C}$ & $\mathrm{H}$ & $\mathrm{C}$ & $\mathrm{C}$ & $\mathrm{HC}$ & \multirow{3}{*}{$\mathrm{H}$} & $\omega_{1}^{\mathrm{H}}$ \\
\hline $\mathrm{H}$ & $\mathrm{H}$ & $\mathrm{H}$ & $\mathrm{H}$ & $\mathrm{H}$ & $\mathrm{H}$ & & $\omega_{2}^{\mathrm{H}}$ \\
\hline $\mathrm{C}$ & $\mathrm{B}$ & $\mathrm{H}$ & $\mathrm{HC}$ & $\mathrm{HC}$ & $\mathrm{C}$ & & $\omega_{3}^{\mathrm{H}}$ \\
\hline
\end{tabular}

Етап 4. Прийняття рішення.

У даному випадку, спочатку знаходяться добутки функцій належності в кожному правилі, а потім поміж них обирається найбільше серед усіх правил для кожного значення $d_{j}, j=\overline{1, m}$, яке i ставиться у відповідність вихідній змінній $Y$.

Остаточне рішення моделі обирається таке, для якого функція належності вихідної змінної $Y$ буде найбільшою для заданих значень контрольованих параметрів $x_{i}, i=\overline{1,6}$ :

$$
Y=\arg \max _{p=1, k_{j}}\left[\omega_{p}^{d_{j}} \prod_{i=1}^{n} \mu^{a_{i} j p}\left(x_{i}\right)\right], j=\overline{1, m}
$$

де $\quad \omega_{p}^{d_{j}}-$ ваговий коефіцієнт $p$-го правила, $p=\overline{1, k_{j}}$, для терму $d_{j} \in\{\mathrm{B} ; \mathrm{C} ; \mathrm{H}\}$ вихідної змінної $Y$.

В якості інструментарію для проектування системи оцінювання якості торгівельного обслуговування покупців використано уніфіковану мова моделювання - Unified Modeling Language (UML) [7-8].

Функціонал розробленої системи оцінювання якості торгівельного обслуговування покупців представлено на діаграмі варіантів використання (рис. 1).

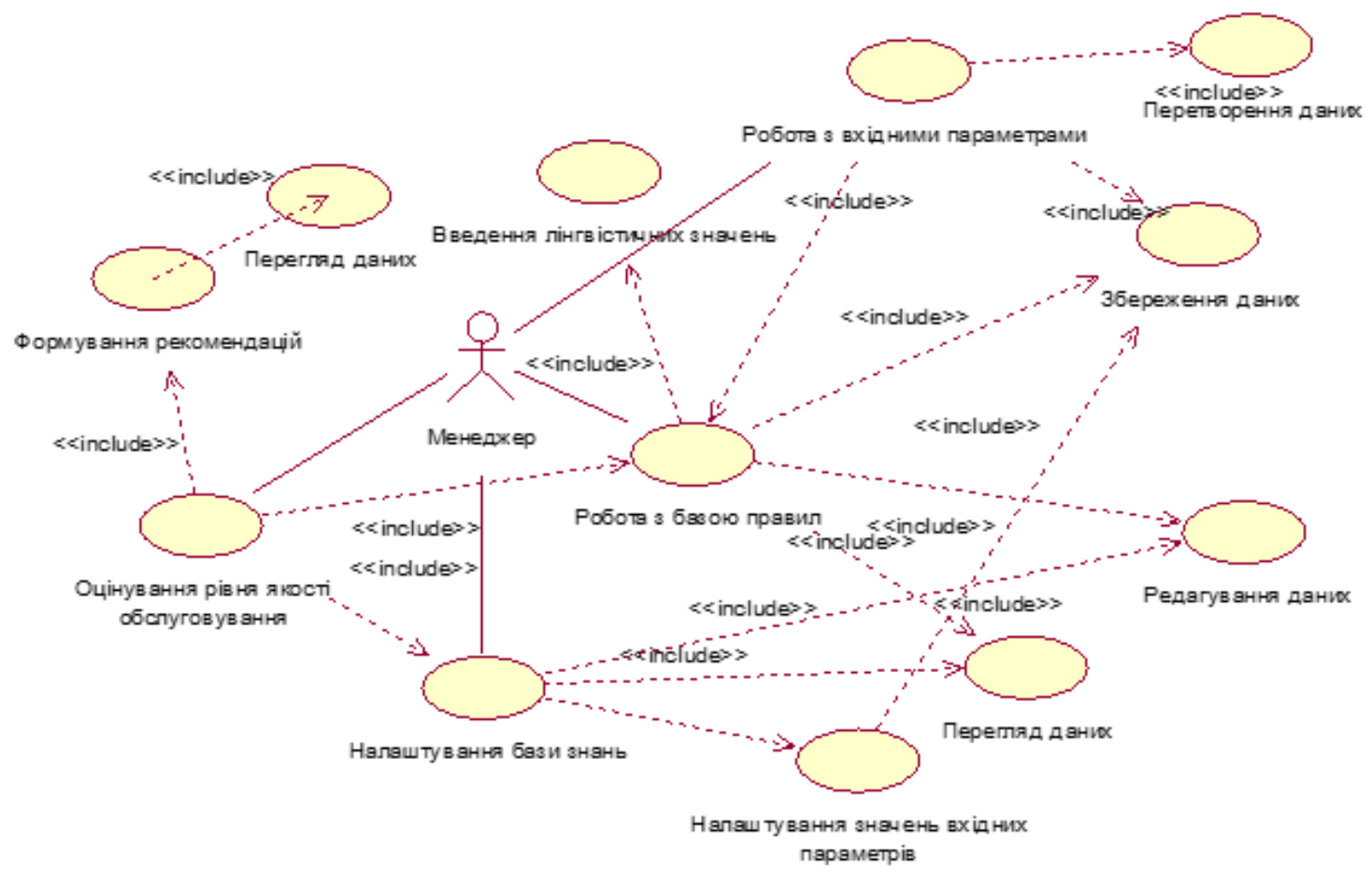

Рис. 1. Діаграма варіантів використання

Загальний алгоритм оцінювання якості торгівельного обслуговування покупців представлено за допомогою діаграми станів (рис. 2). 


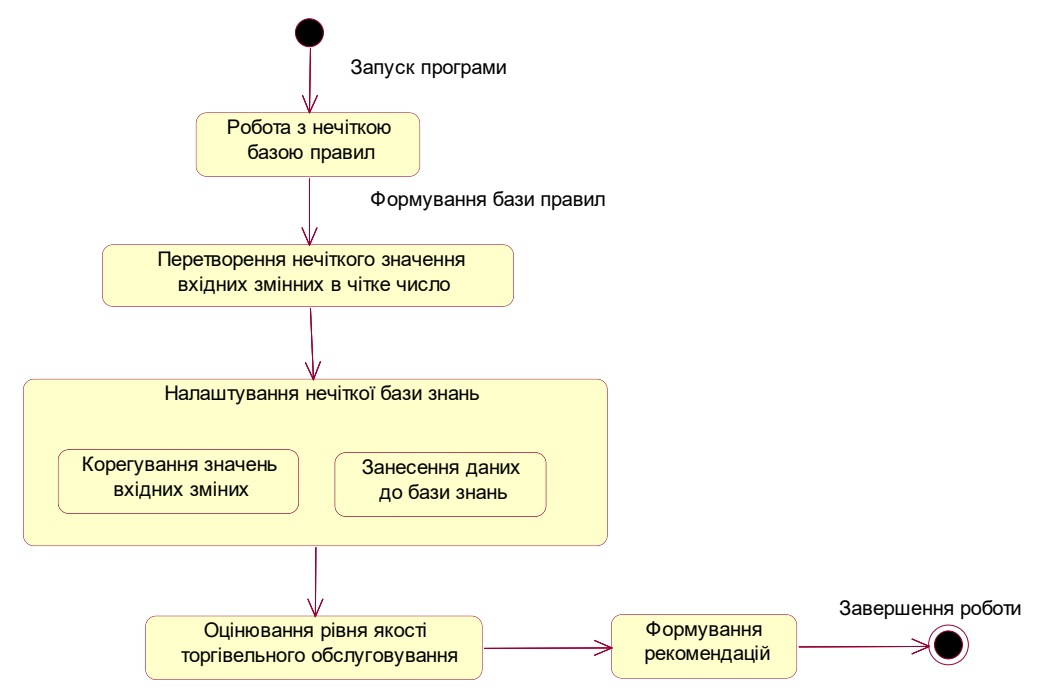

Рис. 2. Діаграма станів

Комп’ютерну реалізацію системи оцінювання якості торгівельного обслуговування покупців здійснено у середовищі Borland Delphi.

Основу розробленого програмного забезпечення для оцінювання якості торгівельного обслуговування покупців складає методологічний підхід до побудови нечіткої економіко-математичної моделі оцінювання якості торгівельного обслуговування покупців торгівельного підприємства, запропонований вище.

Розроблена система оцінювання якості торгівельного обслуговування покупців має наступну структуру (рис. 3):

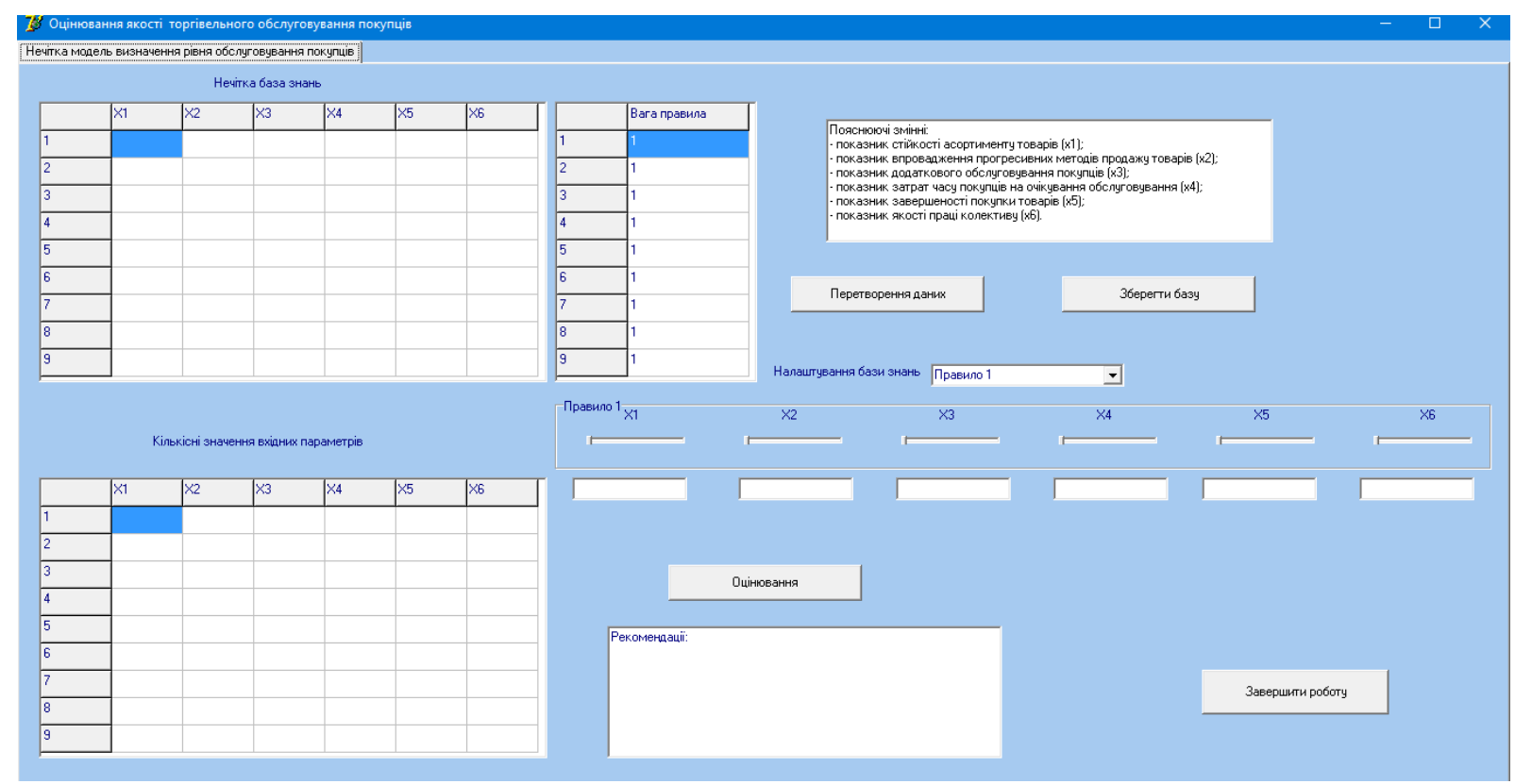

Рис. 3. Головна форма програмного забезпечення

- розділ «Нечітка база знань»: надає можливість побудови нечіткої експертно-лінгвістичної бази правил стосовно визначення рівня якості торговельного обслуговування покупців;

- розділ «Кількісні значення вхідних параметрів»: містить матрицю кількісних значень вхідних показників, що впливають на рівень якості торгівельного обслуговування покупців;

- розділ «Вага правила»: містить значення, яке характеризує значимість правила в моделі;

- розділ «Налаштування бази знань»: забезпечує налаштування значень вхідних параметрів, що надає можливість аналізу впливу зміни значень вхідних параметрів на значення результуючої змінної; 
- розділ «Пояснюючі змінні»: містить перелік контрольованих параметрів, що використані для оцінювання рівня якості торгівельного обслуговування покупців;

- розділ «Рекомендації»: містить результат оцінювання якості торгівельного обслуговування покупців та відповідні рекомендації у відповідності до отриманого розрахункового значення результуючої змінної.

\section{Висновки}

Розроблено систему оцінювання якості торгівельного обслуговування покупців надає можливість для: побудови нечіткої експертно-лінгвістичної бази правил стосовно визначення рівня якості торгівельного обслуговування покупців; перетворення нечіткого значення вхідних змінних в чітке число у відповідності до діапазону виміру кожного контрольованого параметру нечіткої моделі; налаштування значень вхідних параметрів, що забезпечує можливість аналізу впливу зміни значень вхідних параметрів на значення результуючої змінної; визначення рівня якості торгівельного обслуговування покупців.

\section{Список використаної літератури}

1. Формування та впровадження системи управління взаємовідносинами 3 клієнтами на підприємстві [Електронний - pecypc]. http://dspace.wunu.edu.ua/bitstream/316497/31356/1/\%d0\%a1\%d1\%82\%d1\%83\%d0\%bf\%d0\%b0\%d0\%ba\%20 $\%$ d0\%9a.pdf

2. Карпович М. Г. Особливості підвищення культури та якості обслуговування споживачів послуг // М. Г. Карпович, Т. Г. Коса, О. В. Железняк) [Електронний ресурс]. - URL: http://ephsheir.phdpu.edu.ua/bitstream/handle/8989898989/2295/\%D0\%9E\%D1\%81\%D0\%BE

$\% \mathrm{D} 0 \% \mathrm{~B} 1 \% \mathrm{D} 0 \% \mathrm{BB} \% \mathrm{D} 0 \% \mathrm{~B} 8 \% \mathrm{D} 0 \% \mathrm{~B} 2 \% \mathrm{D} 0 \% \mathrm{BE} 9$. pdf?sequence=1\&isAllowed=y.

3. Якість обслуговування та іï оцінка [Електронний ресурс]. - URL: https://pidru4niki.com/16451021/marketing/yakist_obslugovuvannya_otsinka.

4. Матвійчук А. В. Моделювання економічних процесів із застосуванням методів нечіткої логіки: монографія / А. В. Матвійчук. К.: КНЕУ, 2007. 264 с.

5. Ольховська О. Л. Моделювання фінансового стану страхової компанії: монографія / О. Л. Ольховська, А. В. Матвійчук. Краматорськ: ДДМА, 2015. 128 с.

6. Методичні підходи до оцінювання якості торговельного обслуговування покупців [Електронний ресурc]. - URL: http://www.economy.nayka.com.ua/?op=1\&z=5331.

7. Шмулер Д. Освой самостоятельно UML за 24 часа. М.: «Вильямс», 2002. 352 с.

8. Леоненков А. В. Самоучитель UML / А. В. Леоненков. СПб.: БХВ-Петербург, 2004. 432 с.

\section{References}

1. Formuvannya ta vprovadzhennya systemy upravlinnya vzayemovidnosynamy $\mathrm{z}$ kliyentamy na pidpryyemstvi [Elektronnyy resurs]. URL: http://dspace.wunu.edu.ua/bitstream/316497/31356/1/\%d0\%a1\%d1\%82\%d1\%83\%d0\%bf\%d0\%b0\%d0\%ba\%20 $\%$ d0\%9a.pdf

2. Karpovych M. H. Osoblyvosti pidvyshchennya kultury ta yakosti obsluhovuvannya spozhyvachiv posluh // M. H. Karpovych, T. H. Kosa, O. V. Zheleznyak) [Elektronnyy resurs]. - URL: http://ephsheir.phdpu.edu.ua/bitstream/handle/8989898989/2295/\%D0\%9E\%D1\%81\%D0\%BE

$\% \mathrm{D} 0 \% \mathrm{~B} 1 \% \mathrm{D} 0 \% \mathrm{BB} \% \mathrm{D} 0 \% \mathrm{~B} 8 \% \mathrm{D} 0 \% \mathrm{~B} 2 \% \mathrm{D} 0 \% \mathrm{BE} 9$. pdf? sequence=1\&isAllowed=y.

3. Yakist obsluhovuvannya ta yiyi otsinka [Elektronnyy resurs]. - URL: https://pidru4niki.com/16451021/marketing/yakist_obslugovuvannya_otsinka.

4. Matviychuk A. V. Modelyuvannya ekonomichnykh protsesiv iz zastosuvannyam metodiv nechitkoyi lohiky: monohrafiya / A. V. Matviychuk. Kyiv: KNEU, 2007. 264 p.

5. Olkhovska O. L. Modelyuvannya finansovoho stanu strakhovoyi kompaniyi: monohrafiya / O. L. Olkhovska, A. V. Matviychuk. Kramatorsk: DDMA, 2015. 128 p.

6. Metodychni pidkhody do otsinyuvannya yakosti torhovelnoho obsluhovuvannya pokuptsiv [Elektronnyy resurs]. - URL: http://www.economy.nayka.com.ua/?op=1\&z=5331.

7. Shmuler Dzhozef. Osvoy samostoyatelno UML za 24 chasa. Moscow: «Vylyams», 2002. 352 p.

8. Leonenkov A. V. Samouchytel UML / A. V. Leonenkov. - 2-e yzd., pererab. y dop. - StPeterburh: BKHV-Peterburh, 2004. 432 p. 